\title{
A New Exotic Weed \\ on Great Basin Rangelands
}

\section{Considered a botanical oddity, Brassica elongata ssp. integrifolia is becoming a growing weed problem in the West.}

\author{
By James A. Young, Charlie D. Clements and Robert Wilson
}

$\mathrm{W}$ hy didn't someone do something about that weed when it was just starting as small patches? You can substitute the name of your own favorite weed species in this often repeated question. Medusahead, halogeton, Dyers woad, yellow starthistle, the same has been said many times for these and many other very serious weeds of rangelands.

Millions of dollars have been spent on sometimes futile efforts to stop the spread of invasive range weeds once they have become widely established. We are going to attempt to explain, with the example of a new introduced species, why so many weeds are allowed to become major problems over extensive areas of rangeland before suppression programs are initiated.

\section{What is it?}

The first problem you face with an absolutely new introduced plant species is proper identification. Plant taxonomy as practiced by natural resource managers is a comparative science. You look in the appropriate flora and try to find something that looks like what you have just collected. If that fails you ask your peers. If that fails, you send a specimen to the nearest herbarium and ask the experts. If the experts can not find the plant among their broader collection of floras and herbarium specimens you are in trouble.

Modern international information communications make absolute identification a matter of months rather than years, but the time lag between someone first collecting the new species, and correct identification can stretch the interval from actu- al introduction to identification of a new exotic weed into several years. The next delay is in communicating the correct identification of the new introduced plant to a broad spectrum of natural resource managers, weed control regulators, environmentally concerned citizens, and legislatures. That is our purpose in this article.

\section{An example:}

\section{Brassica elongata subspecies integrifolia}

A communication problem is already apparent. We do not have a widely accepted common name for this species. In this case where the subspecies is of great practical importance, communication with a name that requires 38 letters is difficult.

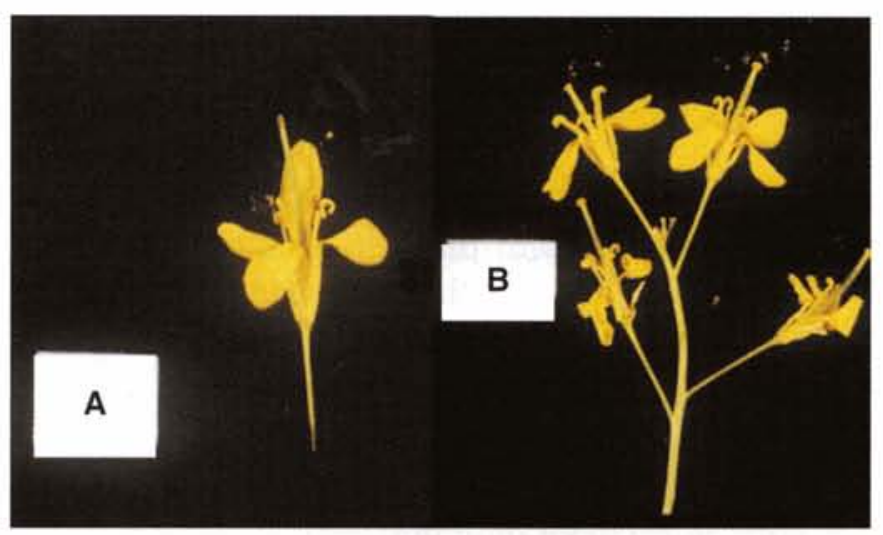

Figure 1. A. Single flower of Brassica elongata ssp. integrifolia showing the typical 4-petal arrangement (cruciferous) of flowers of the mustard family. The sitgma elongates into the seed bearind pod. B. Cluster of flowers. In both figures the scale marker is I $\mathrm{cm}$ (0.4 inches) long. These are quite small flowers, but the aggregate clusters of flowers are highly visible. The color is more intense yellow than the flowers of tumble or tansy mustard, the two most common annual mustards in sagebrush/bunchgrass communities in the Great Basin. 
Halogeton is about the only example of an introduced weed where the scientific genus became the accepted common name.

Ranchers and range managers in eastern Nevada are happy with "Wilson Weed" as a common name for Brassica elongata ssp. integrifolia, but the third author, of this paper, does not share this wish for immortality.

The USDA, Natural Resource Conservation Service data base PLANTS, used elongated mustard as a common name for Brassica elongata. This is unfortunate for two reasons. There is nothing elongated about the plant. It is not as tall as tumble or tansy mustard. Secondly, the weed in question is a very different subspecies from Brassica elongata ssp. elongata. It is different in appearance and area of origin.

Brassica elongata was first collected in 1911 at Linnton, near Portland, Oregon in an area where ships were known to unload ballast. We are not sure which subspecies was collected. The population apparently did not survive and the plant was considered not to be established in North America. In 1968, the noted botanist John Thomas Howell was driving across the Great Basin on what is billed as

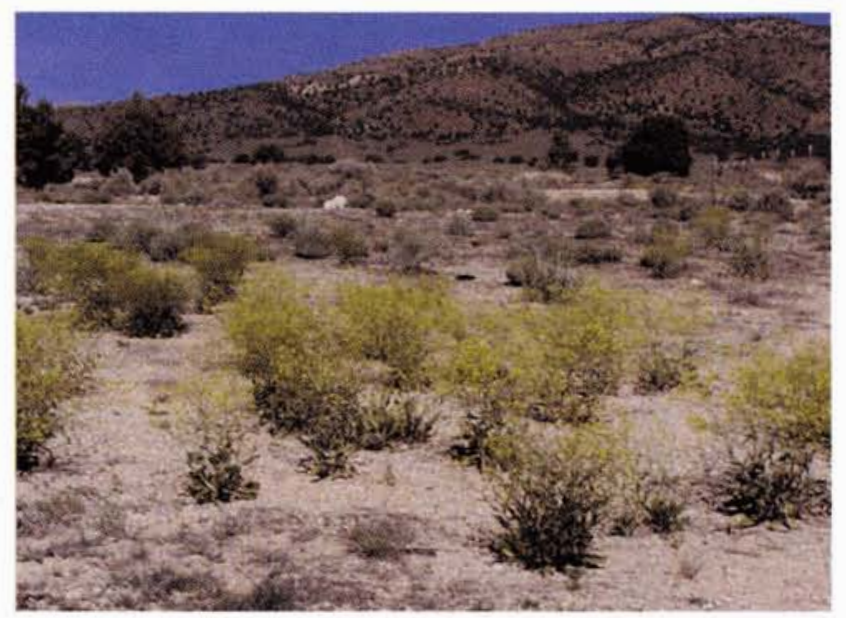

Figure 2. Brassica elongata ssp. integrifolia growing along a secondary road near Fish Creek Ranch in east central Nevada. Associated vegetation in right-of-way includes gray rabbitbrush, bottlebrush squirreltail, and Russian thistle. The natural vegetation in the back ground is a scattered woodland of Utah juniper with a black sagebrush understory. Elevation is about 6,000 feet and the annual precipitation of 6 to 8 inches occurring almost entirely during the winter. "the Loneliest Highway in America," US Highway 50. West of Pancake Summit in Eureka County, he noted a plant flowering he did not recognize. Later he told Phil Martinelli of the Nevada Department of Agriculture that obviously it belonged to the mustard family, but the flower color was not quite right for tumble mustard or the native tansy mustard so he stopped and collected a specimen.

The obvious question is how did this weed reach Eureka, Nevada, and apparently did not establish successfully anywhere else in North America? We do not have a good guess. A key issue is how long it was established when first collected in central Nevada. Perhaps, it came with the camels that were used to pack salt from the desert playas to the silver mills of the mid $19^{\text {th }}$ century.

This illustrates step one in trying to do something about a brand new weed introduction: someone has to realize that the plant is different. John Thomas Howell had computer-like capacity to recognize and recall plants long before computers became common place. Individuals with John

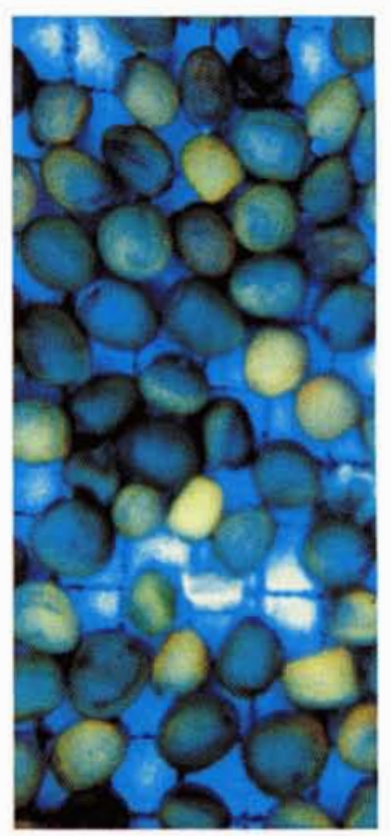

Figure 3. Brassica elongata ssp. integrifolia seed photographed through a microscope. The grid in the background has $1 \mathrm{~mm}$ (0.04inch) squares. The seeds are obviously very small. There is considerable variation in seed coat color and seed size. The various types of seeds produce the same type of plant.
Thomas Howell's level of

botanical knowledge are extremely rare. Ranchers, land managers, hunters, and hikers are the type with the greatest chance for exposure to populations of newly established weed species. It greatly behooves range management professionals to educate the public on the importance of noting the occurrence of what appears to be new plant infestations.

The mustard that John Thomas Howell collected 


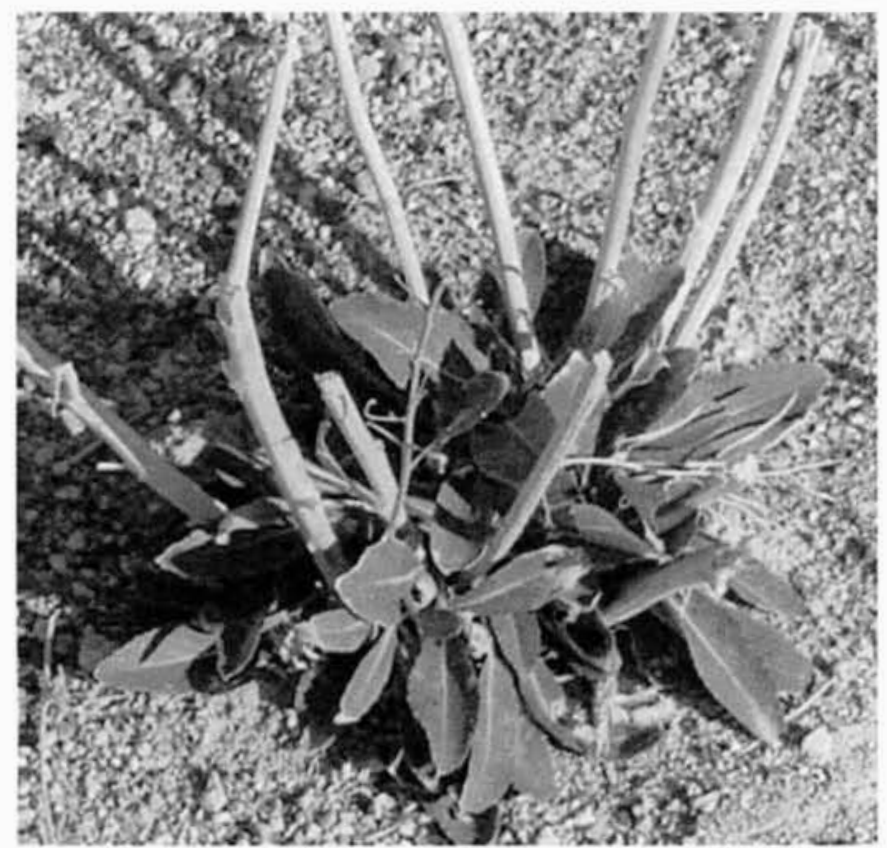

Figure 4. Basal rosette of leaves of Brassica elongata ssp. integrifolia. The leaf blades are entire with only a hint of indentations on the margin. The basal leaves of most other Brassica species that have been introduced to North America are divided to the mid-rib or markedly lobed. The leaf surfaces are waxy dead green and without hairs. The vines of the leaf surface are very prominent. This is a rosette that apparently flowered as a biennial and because the rosette of leaves is still green at the end of the summer, it will probably continue as a perennial. The rosettes are twins. Careful excavation will reveal the plants are connected by a lateral root or perhaps a creeping stem.

in central Nevada was so different even he could not classify it in the correct genus. He thought it was a previously unidentified form of the native genus Thelypodium. His specimen remained unidentified until the 1980s when R.C. Rollins, the recognized world expert on the mustard family, correctly identified the Howell specimen as Brassica elongata ssp. integrifolia.

Why was the correct identification so difficult? There are several species of Brassica that have been accidentally introduced to North America. In California they are especially abundant. During the Spanish pastoral period in Southern California, the introduced mustards spread so fast and grew so tall that vaqueros had difficulty rounding up longhorn cows in yellow flowered mini-jungles.

These weedy mustards are identified by two constant characteristics. First, the basal leaves in outline are divided nearly or completely to the mid-rib. Second, the leaves are often covered with hairs. The basal leaves of the plant collected in Nevada are entire in outline with only a hint of small indentations or waves on the leaf edge. The veins are very prominent in the leaf surface and the leaves are without hairs or glabrous.

When Rollins correctly identified the new plant he discovered that specimens in European herbariums came from semi-arid and arid portions of European and Asiatic Russian and adjacent Central Asian countries. This information brings the chilling prospect that the plant is pre-adapted to the environment of portions of the Great Basin.

While this taxonomic drama was playing itself out over a two decade period, Brassica elongata ssp. integrifolia spread for 200 miles east and west along Highway 50 and north and south for 50 miles along secondary roads.

\section{Is This A New Invasive Range Weed?}

By its rate of dispersal this plant has demonstrated that it can spread without the conscious aid of humans, the original definition of a self invasive weed. As we try to encourage efforts to suppress this weed we continually are told, "It only grows along the road, so it is not a problem."

Every major exotic range weed in the Great Basin,

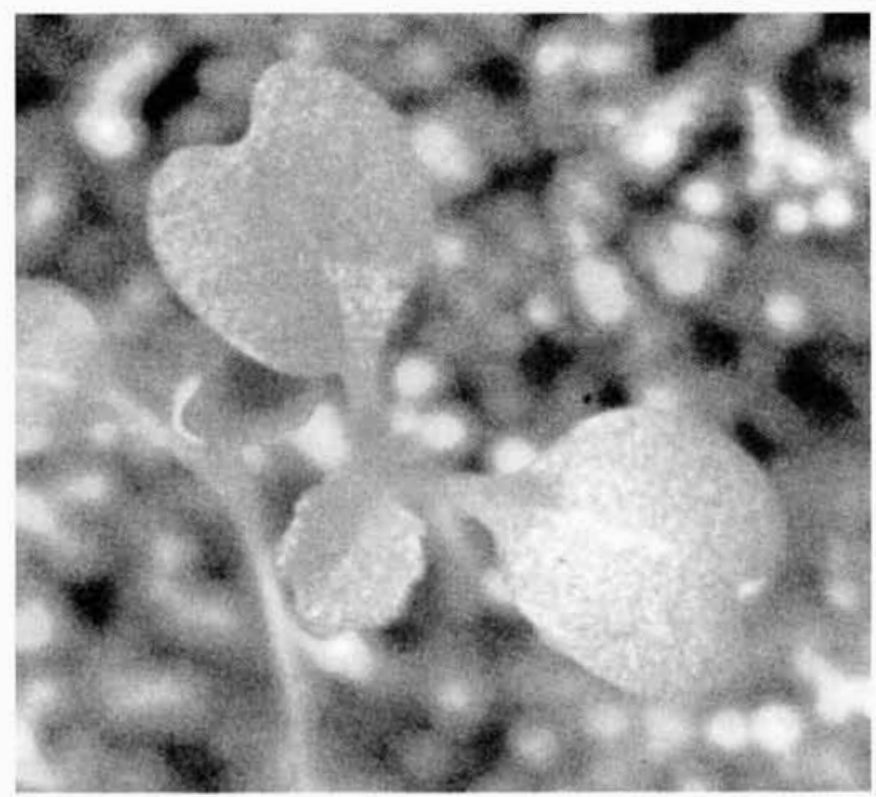

Figure 5. Just emerged seedling of Brassia elongata ssp. integrifolia showing the seed leaf (cotyledon) with very characteristic notch at tip. The cotyledons of most mustard spcies are a slender elliptical shape with a tapered end with no notch. This is one of the few mustards that can be identified to species as a very young seedling. 


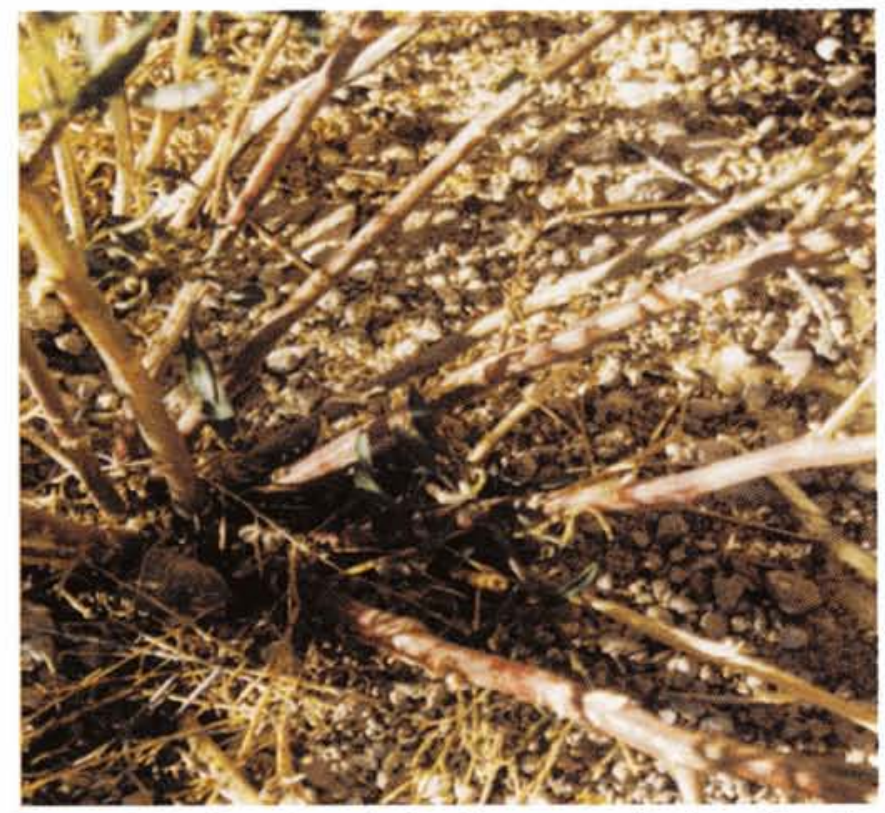

Figure 6. Looking down inside the canopy of a large Brassica elongata ssp. integrifolia plant showing the reddish, angular base of the stems. This is an excellent identification characteristic for this plant.

including cheatgrass, started out as a roadside weed. Many students of the biology of invasive species refer to these roadside communities as the lag phase in the history of an invasive weed, where hybridization, recombinations, and selection results in ecotypes more highly adapted to the local environment. Unfortunately, the next phase is rapid invasion of native plant communities, especially if they are disturbed.

\section{Range Of Adaptation}

Brassica elongata ssp. integrifolia infestations intermingle with winterfat communities at the edge of salt desert environments. They are well established in Utah juniper/black sagebrush woodlands. Infestations extend up through the pinyon/juniper woodlands. The range in elevation of infestations is from 5,500 to 7,400 feet. The range in precipitation of infested areas is from 5 to 6 -inches to 12 to 14 -inches.

\section{Associated Species}

Infestations are not confined to the recently graded shoulders of the highway right-of-ways. Plants are found growing with rabbitbrush, bottlebrush squirreltail, Sandberg bluegrass, and cheatgrass plants. This indicates it can compete in higher levels of secondary succession.

\section{Life Form}

This is where the question of the eventual range and dominance of this species really gets interesting and difficult to interpret. The exotic, invasive species that have come to dominate millions of acres of rangelands in the Intermountain Area are mainly annuals. Russian thistle, barbwire Russian thistle, halogeton, annual kochia, cheatgrass, and medusahead are all examples of successful exotic annuals. Brassica elongata ssp. integrifolia can be a winter annual, biennial, or fairly long lived perennial.

Yes, we have perennial exotics, invasive weeds such as Canada thistle, perennial pepperweed, hoary cress that are problems in the Great Basin, but they are usually restricted to specific habitats where more abundant than normal moisture is available. They are problems in irrigated fields, meadows, riparian and wetland areas and generally are not weeds of upland areas where big sagebrush/bunchgrass communities occur. We have weedy biennial species such as musk thistle or Dyer's woad. We have no experience with a weed that combines so many variable life forms.

\section{Vegetative Propagation}

Most successful exotic perennial weeds have some well developed form of vegetative propagation. Quackgrass has rhizomes. Perennial pepperweed has creeping roots that can form new plants. We have grown new plants from even quite fine fragments of Brassica elongata ssp. integrifolia roots. Plants propagated from root cuttings grow very slowly and have not been induced to flower. In the field, you often find twin rosettes of about the same diameter growing quite close together. Careful excavation usually reveals a shallow lateral root connecting the two plants. Compared to Canada thistle or perennial pepperweed, this new mustard is only a mild threat for propagation from root fragments and will have only a very slow rate of vegetative invasion via creeping roots.

\section{Seed Production and Dispersal}

Flowering is prolonged throughout the late spring, summer, and fall if soil moisture is available. If flowering ceases during the summer drought typical of the Great Basin, it will resume with an early fall rain. Seeds are borne in a long slender pod which, as 
the seeds mature, has indentations between the seeds. Several different size and color forms of seeds can occur in the same pod. The color ranges from slate gray to russet. The biggest and darkest colored seeds occur at the base of the pod, with a reduction in size of one half their diameter or more toward the tapered tip of the pod. The seeds are usually highly viable at maturity. There does not appear to be any differences in germination or subsequent plant characteristics from the different color and size forms of seeds. Seeds of tumble mustard exhibit the same range in color and size variation. Perhaps, this is a mustard family characteristic.

Plants of Brassica elongata ssp. integrifolia that have reached the perennial life form have their stems break at the soil surface and are tumbled by the wind at maturity. Some of the mature seed pods do not shatter until the plants tumble. When the pods shatter, two halves of the pod fall away from a central partition that stays on the plant. Some of the seeds, remain tightly held by the curved lips of these half pods. The half pods are very aerodynamic and can be distributed for long distances. When the tightly held seeds are finally freed from the half pod, they are expelled explosively, adding to the seed dispersal.

Based on the abundance of seed production, seed viability and dispersal mechanisms, Brassica elongata ssp. integrifolia has the potential to be a very invasive annual weed. What is confusing about this assessment is the plant can be a winter annual, but it obviously also can function as a biennial or shortlived perennial. Are these optional life forms benefits or hindrances to invasive weeds?

\section{Breeding System}

Many invasive annual grass rangeland weeds are largely self pollinated. The initial advantage of this breeding system is only one individual has to be introduced to a new site to establish a breeding population. Brassica species are the classical examples among botanists of plants that are self incompatible for pollination. We have observed that isolated plants of Brassica elongata ssp. integrifolia will flower profusely, but not set a single seed.

Superficially this would seem as a great disadvantage for an invasive weed, but yellow starthistle and

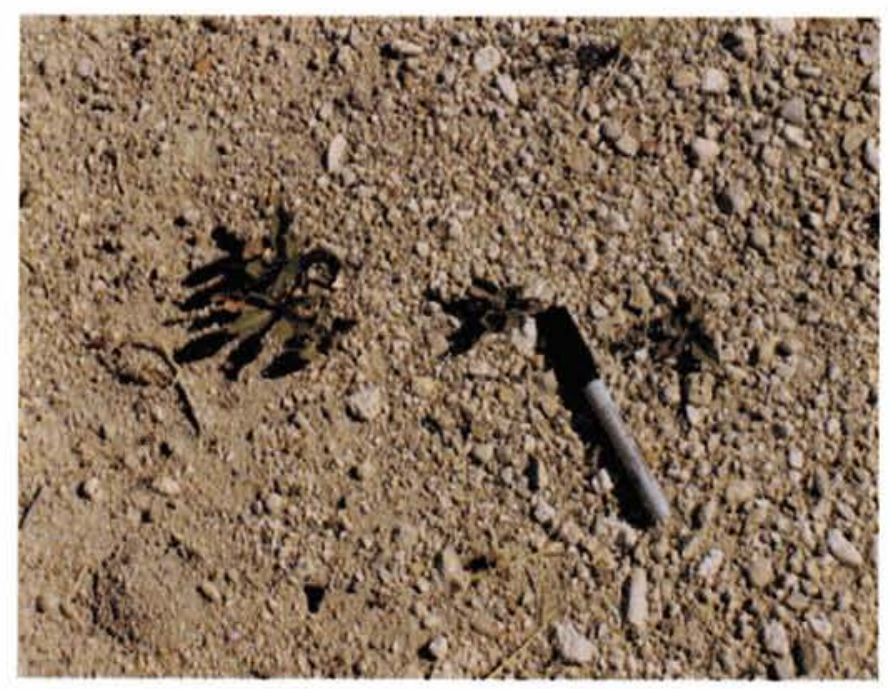

Figure 7. Seedlings of Brassica elongata ssp. integrifolia in the field. Characteristically the seedlings occur in clusters of various sized rosettes. Pen is 5 inches $(13.75 \mathrm{~cm})$ long.

Russian knapweed share the same characteristic and both have done quite well as invasive species.

\section{The Current Status}

The current status of Brassica elongata ssp. integrifolia is best described as a botanical oddity. Admittedly, an apparently rapidly spreading botanical oddity, the species has no status on weed lists or legal recognition as a noxious weed by State or Federal governments.

The environment where Brassica elongata ssp. integrifolia has spread is home to a few irrigated alfalfa fields, mainly on Desert Land Entries. It can not be considered a high intensity agricultural area. Perhaps, if this species eventually reaches such an area it will constitute a problem as an agronomic weed. There is no evidence the species is utilized as forage, even by jackrabbits. There is no record apparent in the European or Russian literature that indicates the herbage is poisonous to livestock. Of course the same was once said for halogeton. In the Russian literature there is virtually no mention of the subspecies except in floras.

Local weed control districts and land management agencies are strapped for funds to control exotic weeds that have already been proven to be highly invasive and often designated as noxious species. They do not have the time or resources to attempt a suppression program on what remains a roadside species. 
Control might be quite easy with application of a phenoxy herbicide, but revegetation of roadsides to provide post-control biological suppression is not a simple process, especially in the more arid portions of the habitat invaded by Brassica elongata ssp. integrifolia. On secondary roads where the right-ofway is not fenced, linear seedings of perennial species to provide stable communities for invasive weed suppression are nearly impossible to establish because they attract grazing and browsing animals.

Look at the illustrations. Check the identification characteristics that are presented. Someday this alien may be spotted along your familiar roadways. You can say. "I remember when that plant was a botanical oddity in the desert of eastern Nevada, why didn't they do something about it?

About the authors: James Young and Charlie Clements are Range Scientists, USDA, Agricultural Research Service, 920 Valley Road, Reno,Nevada 89512; e-mail jayoung@scs.unr.edu Robert Wilson is an Extension Educator with the University of Nevada, 995 Compton Street, Ely, Nevada 89301.

\section{MEMBERSHIP}

\section{Makes A D ifference}

Renew your SRM membership today, and ask others to join this valuable organization. Visit www.rangelands.org for more information or call the SRM office at 303-986-3309 and visit with Lesley Radtke, Director of Membership. 